\title{
The influence of seasonal light variations on the growth of Sphaerotilus natans
}

\author{
K1. Mechsner \\ Swiss Federal Institute of Technology Zürich and Federal Institute for Water Resources and Water Pollution \\ Control, CH-8600 Dübendorf, Switzerland
}

Keywords: Sphaerotilus natans, sewage fungus, seasonal development, light inhibition, model flowing water channels

\begin{abstract}
The influence of the sunlight on the seasonal development of Sphaerotilus natans was investigated in model flowing water channels. To exclude interfering factors such as either substrate variations or competition, special vessels containing pure cultures of Sphaerotilus natans were used. These were submerged on the bottom of the channels, and could be shaded completely with metal plates.

The results showed complete inhibition of Sphaerotilus natans growth between May and August, when daylight periods were longer than 13 hours. During the other months, no growth in hibition relative to growth under shaded conditions, was observed. The physiological reasons for light inhibition are discussed.
\end{abstract}

\section{Introduction}

The development of Sphaerotilus natans, the so called 'sewage fungus', in polluted streams is determined by the season. Liebmann (1951), Scheuring \& Höhnl (1956) and Curtis (1969) described massive growths of the bacterium during winter. During ecological experiments in model flowing water channels Eichenberger \& Wuhrmann (1966) and Eichenberger $(1967 \mathrm{a}, 1967 \mathrm{~b}, 1972)$ repeatedly observed a distinct winter maximum for the growth of Sphaerotilus natans. Eichenberger \& Wuhrmann (1969) attributed variations in the growth and development of Sphaerotilus natans to temperature effects, particularly the effect of temperature on competition with mesophilic organisms which have relatively higher temperature optima. However, in another study, Eichenberger (1967b) excluded temperature effects and found that effects resulting from the availability of growth factors, e.g., vitamin B 12 , and possible inhibition by light might be responsible.

The bactericidal effect of ultraviolet and visible light is well known and Epel (1973) reported that radiation between 330 and $490 \mathrm{~nm}$ would either kill or inhibit many microorganisms. Grigsby \& Calkins (1980) found that after removing the shorter wavelenghts $(<325 \mathrm{~nm})$ by either optical filters or as a result of the optical characteristics of pollutants present in wastewater, sunlight was still capable of killing coliforms. The suppression of marine nitrifying bacteria by light has been demonstrated by Horrigan et al. (1981) and by Olson (1981).

It seems probable that sunlight is a determinative ecological factor for the growth of Sphaerotilus natans and it was the aim of this investigation to develop an understanding of seasonal light variations on the development of the bacterium using as natural conditions as possible, but excluding major interfering ecological factors such as competition and substrate variability. To achieve this, special vessels containing pure cultures of Sphaerotilus natans were submerged in model flowing water chanels and the growth of the organism was measured under conditions where the vessels were exposed to direct sunlight and where they were in shadow. 


\section{Methods and materials}

Organism: Sphaerotilus natans (Kütz.)

Isolation. Naturally occuring Sphaerotilus natans flocs from model flowing water channels were rinsed with sterile buffer solution and ground by vigorous shaking with sterile quartz sand. The suspensions were increasingly diluted and plated on the following medium: peptone $0.1 \mathrm{~g}$, lactic acid $0.5 \mathrm{~g}$, gelatine $150 \mathrm{~g}$ per liter of $0.015 \mathrm{M}$ phosphate buffer $(\mathrm{pH} 8,0)$. Incubation at $22^{\circ} \mathrm{C}$ followed. The outer filaments of the colonies were cut off and reinoculated. This procedure were repeated until the isolated colonies were no longer contaminated with other organisms.

Culture Techniques. Freshly isolated Sphaerotilus natans strains are cultured and maintained at $22{ }^{\circ} \mathrm{C}$ in $200 \mathrm{~m}$-Erlenmeyer-flasks containing $50 \mathrm{ml}$ of the following substrate solution (Sph III): peptone $1 \mathrm{~g}$, sucrose* $1 \mathrm{~g}$, trace metal solution $1 \mathrm{ml}$ per liter of $0.015 \mathrm{M}$ phosphate buffer ( $\mathrm{pH} 8.0)$.

Growth. The dry weight of the harvested biomass was used as the parameter for Sphaerotilus natans growth. It was determined by either centrifugation or membranfiltration of the bacterial suspensions and subsequent drying of the residue for 1 hour at $103^{\circ} \mathrm{C}$.

\section{Materials}

Model Flowing Water System. Our model consisted of 4 concrete channels with a trapezoidal profile (base $0.25 \mathrm{~m}$, top $0.35 \mathrm{~m}$, depth $0.19 \mathrm{~m}$ ) $200 \mathrm{~m}$ in lenght at an incline of $1.5 \%$. The channels had a gravel covered bottom and could be filled to a depth of $0.12 \mathrm{~m}$ with ground water to which sewage could be added (Wuhrmann, 1964).

\section{Experimental Culture Vessel (Fig. 1)}

For the cultivation of Sphaerotilus natans in the model flowing water channels, $200 \mathrm{ml}$ pharmaceutical, flat flasks were used (a). The flasks were closed

\footnotetext{
* To inhibit degeneration of the organisms, alteration of the $\mathrm{C}$-source by using either different carbohydrates or lactic acid is recommended.
}

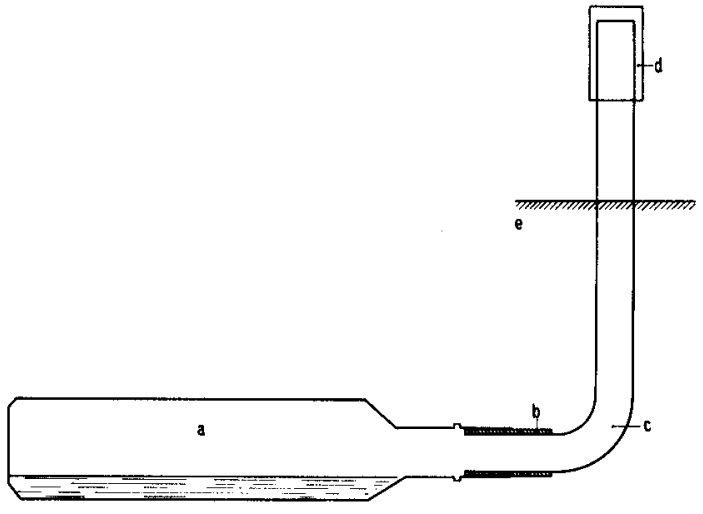

Fig. 1. Experimental vessel for culturing Sphaerotilus natans in the flowing water channels. a: pharmaceutical (Bacovis) flask, vol. $200 \mathrm{ml}$; b: silicon sleeve; c: breathing tube, diameter $13 \mathrm{~mm}$, height $150 \mathrm{~mm}$; : aluminium cap; e: water surface of the channel.

with a breathing tube, bent through $90^{\circ}$ (c), which was sealed into the neck of the flask by a silicon rubber sleeve (b). The breathing tube was fitted with an alluminium cap (d) in order to maintain sterility. The flasks were clipped on metal plates in three lines (a, b, c, Figs 2-5) and submerged in one of the experimental channels with the breathing tubes above the water surface (e). The depth $(5-7 \mathrm{~mm})$ and the surface area $\left(\sim 80 \mathrm{~cm}^{2}\right)$ of the substrate $(50 \mathrm{ml})$ in each vessel guaranteed an optimum oxygen supply. The channels could be partly covered by metal plates as required.

\section{Methods}

The centrifuged and washed Sphaerotilus natans flocs were quartz-ground to give a homogenous cell suspension for inoculation into the medium Sph III. $50 \mathrm{ml}$ of the inoculated medium was transferred to each culture flask and the flasks were then submerged in the channel so that half were in the light and half in darkness. However, during some five to six hours between 11.00 and 17.00 the channels were subjected a variable degree of shading because of the proximity of a building.

Depending on the rate of growth of the Sphaerotilus natans, samples were taken at appropriate intervals, using the complete contents of one vessel for dry weight measurement. Attached flocs were removed with a rubber scraper. 


\section{Results and discussion}

The experimental results are shown in Figures 2-5. For Sphaerotilus natans cultures grown in darkened flasks, virtually the same quantity of cells were produced during the whole year irrespective of season (Figs. 2-5). For Sphaerotilus natans grown in flasks exposed to the natural diurnal cycle, similar quantities of cells to those produced in the darkened flasks were produced between October and March (Figs 2, 5). However, for Sphaerotilus natans cultures ex posed to the natural diurnal cycle between May and August, complete inhibition of growth was observed (Figs 3, 4). For Sphaerotilus

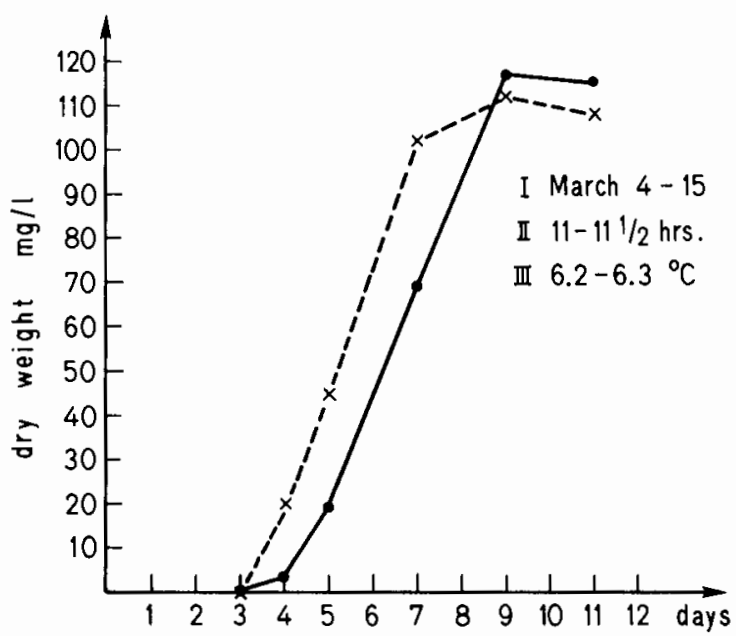

Figs. $2 \& 3$. .--. exposed vessels $\mathrm{x}-\ldots \mathrm{x}$ darkened vessels

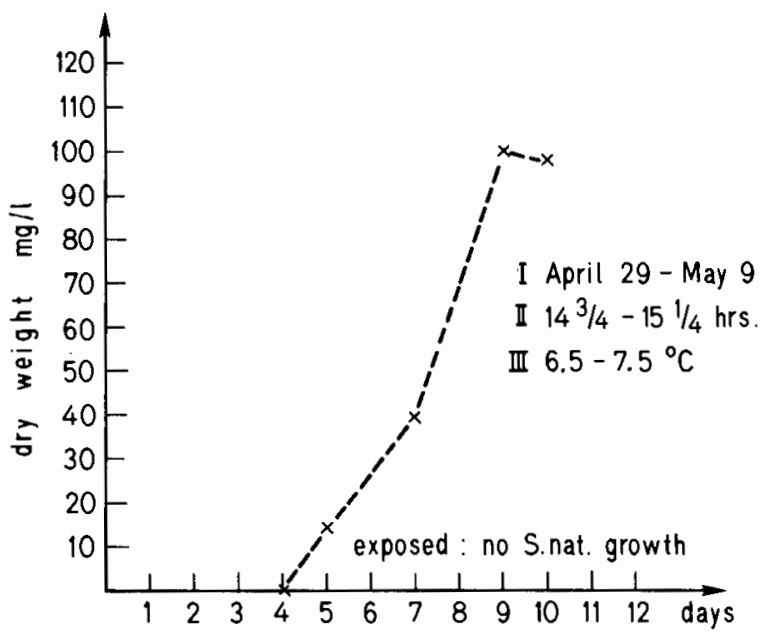

natans cultures subjected to partial shading, at the end of August and in early September, varying levels of growth inhibition, from 0-100 percent, were observed (Figs 4, 5).

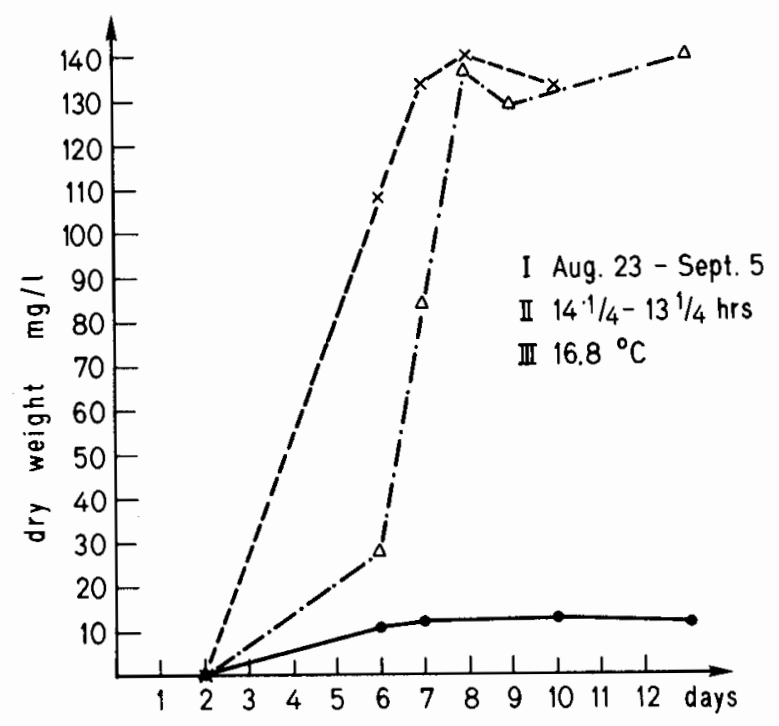

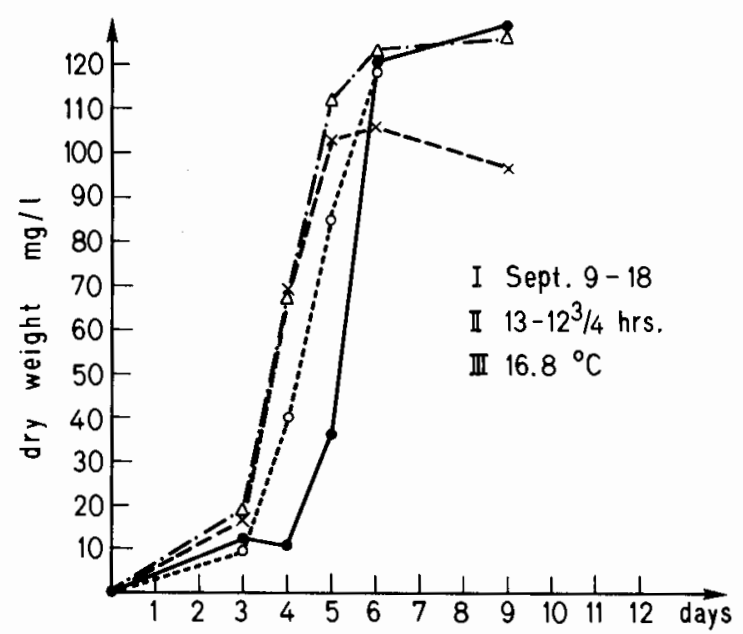

Figs. 2-5. Influence of the seasonal light periods on the development of Sphaerotilus natans, a, b, c-situation of the reaction vessels in the channel; I-date of the experiment, II-light period, III-temperature of the channel water. 
The results cited clearly demonstrate seasonal effects on the development of Sphaerotilus natans. With the exception of this transient period when variable shading was causing inconsistent effects in growth inhibition, it can be seen that there is a relatively sharp treshold of response. This threshold can be defined as $13 \mathrm{~h}$ of daylight. Shorter periods of light cause no effect, but longer periods result in complete inhibition of the growth of Sphaerotilus natans. It is important to note that Sphaerotilus natans growing free in the natural ecosystem of the model channels shows only a reduction of growth during summer time, i.e. only partial inhibition (Eichenberger, pers. commun.) for differences in conditions between Sphaerotilus natans growing in flask cultures and directly in the channels were that in the flasks, significantly higher concentrations of nutrients were available, and in the channels, Sphaerotilus natans were able to attach and grow in shaded niches provided by tufts of growing autotrophs. Discontinuously radiated cell aggregates also have the physiological possibilities of repairing light damages. Only $10 \mathrm{~cm}$ below the surface of natural waters with an abundant growth of plants and algae, Westlake (1966) measured a $90 \%$ decrease of the light transmission.

Light can be regarded as the major causitive factor for the results reported here. The design of the experimental system excluded changes in substrate and competition as interfering factors and temperature did not correlate with the results in any respect.

To interpret the effects reported one should refer to Favre (1975) who investigated physiological aspects of light inhibition of Sphaerotilus natans in vitro using a $\mathrm{Hg}$-lamp for the radiation of the cells. Starting with light intensities of $1.4 \mathrm{~mW} \mathrm{~cm}^{-2}$ Favre found, within a spectral range of $305-540 \mathrm{~nm}$, an increasing inhibition of the respiration, with total suppression of respiration and growth at intensities in excess of $10 \mathrm{~mW} \mathrm{~cm}^{2}$. With exposures shorter than $3 \mathrm{~h}$, the reactions were reversible, provided the medium contained organic $\mathrm{N}$-sources for the repair of damaged functional units of the protein. According to Epel (1973), photodestruction of cytochromeoxidase by visible light is one of the major reasons for the inhibition of respiration and growth. There is also evidence for suppression of DNA synthesis in E. coli by UV-radiation. (Bridges \& Mottershead, 1977, 1979).

The light intensities for total inhibition, reported

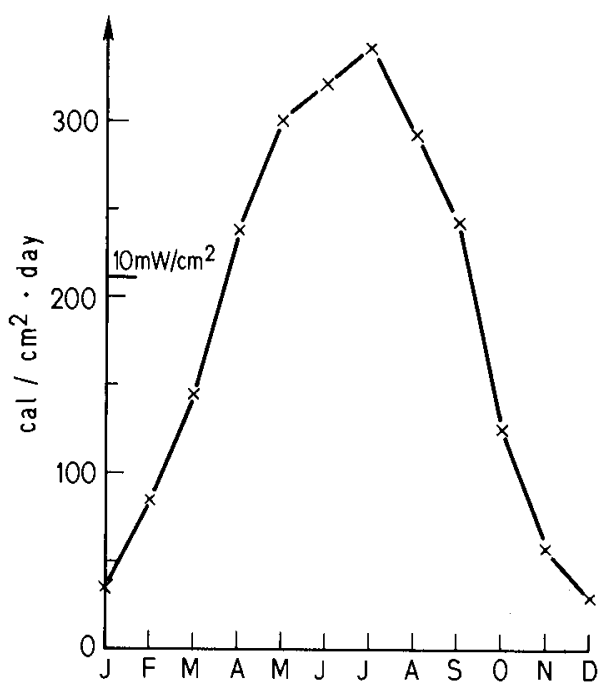

Fig. 6. Seasonal course of the average light intensities in the range of the experimental channels. Integrated values of the years 1971-73 (E. Eichenberger, pers. commun.).

by Favre correspond to natural values that have been observed by Eichenberger (pers. commun.) for three years at the surface of the experimental channels during the period April to September (Fig. 6). Westlake (1966) has reported similar seasonal variations for North American rivers.

It is surprising that there are no greater differences between the maximal effective light intensities in vivo and in vitro, particularly if one considers that in Favre's experiments, only wavelengths $<540 \mathrm{~nm}$ seemed to be effective, whereas Eichenberger measured the complete visible light spectrum including the infrared part. Furthermore, it can be assumed that a part of the short wave radiation was adsorbed by the glasswalls of the culture vessels. However, in considering the total light inhibition during the period May until September, one should pay regard to the data of Eichenberger (pers. commun.) which were based on integrated daily values. Relatively high intensity peaks and long exposition periods to radiation caused severe damage within the cells, which cannot be repaired during a few dark hours.

By using the experimental channel system it was shown that the growth of Sphaerotilus natans was directly influenced by the intensity and the duration of sunlight. Amongst the many known and unknown ecological parameters, light is one of the 
most significant factors influencing seasonal changes, not only concerning the appearance of Sphaerotilus natans but also the composition and synthrophism of the biocoenosis of entire rivers.

\section{Summary}

The development of Sphaerotilus natans is markedly influenced by light and by the length of day. During our experiments, using model flowing water channels, Sphaerotilus natans growth was completely inhibited from May to August. However, with the exception of only a minor transient period there was no measurable effect on Sphaerotilus natans growth during the other months of the year.

\section{Acknowledgments}

I am indepted to Prof. K. Wuhrmann for initiating this investigation, to Dr. E. Eichenberger for his valuable advice concerning the channel experiments, and to Prof. G. Hamer for commenting on the manuscript.

\section{References}

Bridges, B. A., R. P. Mottershead \& M. H. L. Green, 1977. Cell Division in Escherichia coli B-S-12 is HyperSensitive to DNA Damage by UV Light. J. Bacteriol. 130: 724-728.

Bridges, B. A.\& R. P. Mottershead, 1979. Inactivation of Escherichia coli by Near UV Light and 8 Metoxypsoralen Differ- ent Responses of strains B-R and K-12. J. Bacteriol. 139: 454-459.

Curtis, E. J. C., 1969. Sewage Fungus: Its Nature and Effects. Wat. Res. 3: 289-3 I1

Eichenberger, E. \& K. Wuhrmann, 1966. Ueber jahreszeitliche Veränderungen der Besiedlungsdichte in Modellfliessgewässern mit verschiedener Abwasserbelastung. Verh. int. Ver. Limnol. 16: 888-896.

Eichenberger, E., 1967a. Oekologische Untersuchungen an Modellfliesswässern, 1. Die jahreszeitliche Verteilung der bestandesbildenden pflanzlichen Organismen bei verschiedener Abwasserbelastung. Schweiz. Z. Hydrol. 29: 1-31.

Eichenberger, E. 1967b. Oekologische Untersuchungen an Modellfliessgewässern, 2. Jahreszeitliche Veränderungen der Biomassebildung bei verschiedenen Abwasserbelastungen. Schweiz. Z. Hydrol. 29: 32-51.

Eichenberger, E., 1972. Oekologische Untersuchungen an Modellfliessgewässern, 3. Die jahreszeitlichen Veränderungen im Verhältnis von heterotropher zu phototropher Biomasse bei verschiedenen Abwasserbelastungen. Schweiz. Z. Hydrol. 34: 155-72.

Epel, B. L., 1973. Inhibition of Growth and Respiration by Visible and Near-Visible Light, Photophysiology 8: 209-229.

Favre, J., 1975. Inhibition de la respiration et de la croissance de Sphaerotilus natans par la lumière visible et UV-proche à forte intensité. Thése, Juris-Verlag Zürich, 1975.

Grigsby, P. \& J. Calkins, 1980. Inactivation of a Natural Population of Coliform Bacteria by Sun Light. Photochem. Photobiol. 31: 291-294.

Horrigan, S. G., A. F. Carlucci \& P. M. Williams, 1981. Light Inhibition of Nitrification in Sea Surface Films. J. mar. Res. 39: $557-566$.

Liebmann, H. 1951. Handbuch der Frisch- und Abwasserbiologie. Oldenbourg, München.

Olson, R. J., 1981. Differential Photo Inhibition of Marine Nitrifying Bacteria, a Possible Mechanism for the Formation of the Primary Nitrite Maximum. J. mar. Res. 39; 227-238.

Received 20 May 1983; in revised form 22 March 1984; accepted 24 May 1984 